\title{
Comparison of Percutaneous Nephrolithotomy Outcomes in the Elderly and Young Population
}

\section{Yaşlı ve Genç Popülasyon Arasında Perkütan Nefrolitotomi Sonuçlarının Karşılaştıııması}

\author{
(1) Efe Önen, (1) Volkan Çağlayan \\ Bursa Yüksek Ihtisas Training and Research Hospital, Clinic of Urology, Bursa, Turkiye
}

What's known on the subject? and What does the study add?

Percutaneous nephrolithotomy (PNL) is a minimally invasive procedure. However, some complications which are generally minor may occur following procedure. Concerns about PNL success and -associated complications in elderly population are a matter for urologists. As an experienced center, we decided to share our data with readers.

\begin{abstract}
Objective: We aimed to compare the efficacy and safety of percutaneous nephrolithotomy (PNL) in the young and elderly population. Materials and Methods: The data of 3362 adult patients who underwent PNL were retrospectively evaluated. The patients were divided into two age groups of 18-64 (young patients) and $\geq 65$ years (elderly patients). The groups were compared in terms of patient characteristics, operative data, surgical outcomes, and complications.

Results: The median ages were 69 (65-85) and 47 (18-64) years and the mean surface areas of the stones were 412 (245.5-700) and 417 (225-780) $\mathrm{mm}^{2}$ in the elderly and young groups, respectively. There were no statistically significant differences between the groups in terms of laterality, access number, stone location, presence of hydronephrosis, Guy's Stone score, mean operative time, mean hospitalization days, and the type of anaesthesia ( $p>0.05)$. Preoperative haemoglobin and glomerular filtration rate (GFR) values were statistically lower in the elderly group, while postoperative haemoglobin drop and postoperative $4^{\text {th }}$ week GFR changes of the groups were not significantly different $(p>0.05)$. There was no significant difference between the total complication rates of the groups $(p=0.835)$. Stone-free rate was higher in the elderly population, while success rates were similar in both groups ( $p=0.002$ and $p=0.605$, respectively).
\end{abstract}

Conclusion: PNL is a safe and effective treatment modality regardless of the age of patient.

Keywords: Percutaneous nephrolithotomy, Elderly patient, Complication

Öz

Amaç: Genç ve yaşlı popülasyonlarda perkütan nefrolitotominin (PNL) etkinliğini ve güvenilirliğini karşılaştırmayı amaçladık.

Gereç ve Yöntem: PNL uygulanan 3352 yetişkin hastanın verileri retrospektif olarak değerlendirildi. Hastalar 18-64 yaş ve 65 yaş ve üstü olmak üzere iki yaş grubuna ayrıldı. Gruplar hasta özellikleri, ameliyat verileri, cerrahi sonuçlar ve komplikasyonlar açısından karşılaştırıldı.

Bulgular: Ortanca yaş yaşlı grupta 69 (65-85), genç grupta 47 (18-64) idi. Ortalama taş yüzey alanı sırasıyla 412 (245,5-700) mm² ve 417 (225-780) idi. Gruplar arasında taraf, erişim sayısı, taş yerleşimi, hidronefroz varlığı, Guy Taş skoru, ortalama ameliyat süresi, ortalama hastanede yatış günü ve anestezi tipi açısından istatistiksel olarak anlamlı bir fark yoktu $(p>0,05)$. Ameliyat öncesi hemoglobin ve glomerüler filtrasyon hızı $(G F R)$ değerleri yaşlı grupta istatistiksel olarak düşük iken, ameliyat sonrası hemoglobin düşmesi ve ameliyat sonrası 4. hafta GFR değişiklikleri anlamlı olarak farklı değildi $(p>0,05)$. Grupların toplam komplikasyon oranları arasında anlamlı fark yoktu $(p=0,835)$. Taşsızlık oranı yaşlı popülasyonda daha yüksek, başarı oranları her iki grupta benzerdi (sırasıyla $p=0,002$ ve $p=0,605$ ).

Sonuç: PNL, hastanın yaşından bağımsız olarak güvenli ve etkili bir tedavi yöntemidir.

Anahtar Kelimeler: Perkütan nefrolitotomi, Yaşıı hasta, Komplikasyon

Correspondence: Volkan Çağlayan MD, Bursa Yüksek Ihtisas Training and Research Hospital, Clinic of Urology, Bursa, Turkiye

Phone: +90 5057824369 E-mail: volkantuysuz@hotmail.com ORCID-ID: orcid.org/0000-0001-9303-9585

Received: 05.06 .2020

Accepted: 04.08 .2020

Cite this article as: Önen E, Çağlayan V. Comparison of Percutaneous Nephrolithotomy Outcomes in the Elderly and Young Population. J Urol Surg 2020;7(4):263-270

๑Copyright 2020 by the Association of Urological Surgery / Journal of Urological Surgery published by Galenos Publishing House. 


\section{Introduction}

The incidence of kidney stones among the elderly population has demonstrated an increasing trend together with the longer lifespans of the elderly population. Patients with kidney stones are prone to recurrent urinary tract infections and deterioration in renal function with a decrease in the glomerular filtration rate (GFR), which is a natural process of ageing, and many endourologists prefer surgical treatments over conservative interventions $(1,2)$. The presence of comorbidities that occur with ageing may increase the complication rates associated with the indicated surgical procedures and cause a delay in postoperative recovery, thereby increasing the length of hospitalization (36). Since the time Fernström and Johansson (5) first described the percutaneous nephrolithotomy (PNL) in the late twentieth century, it has replaced open surgery for the treatment of kidney stones due to its less invasive nature, and has become the preferred method for all age groups (6). There are many studies in literature that have evaluated the efficacy and safety of PNL in the elderly patients. However, the success rates of the operation are similar in the young and elderly populations, the complication rates vary between the two (6-10). Moreover, limited studies have evaluated the effect of PNL on the renal function in the elderly patients. Our centre is one of Turkey's largest renal stone units and PNL has been employed for all age groups since 2003. The aim of this study was to compare the efficacy of PNL in the young and elderly populations.

\section{Materials and Methods}

Approval for the study was granted by the Institutional Ethics Committee (approval no: 2011-KAEK-25 2020/01-06, date: 29.01.2020). A retrospective evaluation was made of the data of 3362 adult patients who underwent PNL between 2003 and 2017 at our centre. The patients were divided into two age groups of $18-64$ and $\geq 65$ years. Patients aged $<18$ years or lacking preoperative or postoperative data were excluded from the study.

Detailed physical examinations, blood count and biochemistry assays, urine analysis, and urine culture were performed preoperatively. All the patients underwent preoperative kidneyureter-bladder radiography (KUB), urinary ultrasonography (USG), and unenhanced spiral computed tomography (sCT). Surface area of the stone was calculated using the formula "length $\times$ width $\times 0.25 \times \pi$ ". Preoperative data of age, gender, surgical history for renal stones, stone characteristics and its surface area and location, presence of hydronephrosis, Guy's Stone score; and intraoperative data such as access number, operation time, and type of anaesthesia, were recorded from the centre's database.

\section{Surgical Technique}

Under C-arm fluoroscopy, a 6 or 7 French (F) ureteral catheter was inserted. All the procedures were performed in the prone position. The renal collecting system was visualised with retrograde pyelography and an access tract was achieved under fluoroscopic guidance. Upon gaining access, the urologist performed Amplatz dilation, and a $30 \mathrm{~F}$ sheath was placed in position. Stone fragmentation was performed with a pneumatic lithotripter. Larger fragments were extracted using a stone basket or a grasper and irrigation was performed to remove the smaller fragments. Clearance of the stone fragments was assessed with fluoroscopy. At the end of the procedures, a re-entry nephrostomy catheter was placed, and antegrade pyelography was performed to check for extravasation and colonic injury. On the first postoperative day, KUB was performed for all patients.

A record was made for each patient's length of hospital stay, duration of nephrostomy, postoperative complications, stonefree (SF) rate, clinically insignificant residual fragment (CIRF) rate, success rate of the operation, and postoperative $4^{\text {th }}$ week GFR according to the Chronic Kidney Disease Epidemiology Collaboration formula (CKD-EPI) (11).

For the determination of stone clearance, KUB and USG were used for patients with radiopaque stones and CT was used for radiolucent stones at 4 weeks postoperatively. Patients without any residual fragments were defined as SF. The presence of residual fragments $>4 \mathrm{~mm}$ was defined as unsuccessful. CIRFs were defined as fragments $\leq 4 \mathrm{~mm}$ that were non-obstructing, non-infectious, and asymptomatic. The operation was defined as successful if the patients had no residual fragments or CIRFs. PNL-associated complications were classified according to the Modified Clavien Classification (12).

\section{Statistical Analysis}

Data obtained in the study were analysed statistically using IBM SPSS version 19 software (Chicago, IL, USA). Continuous variables were stated as mean \pm standard deviation or median (minimummaximum) values and categorical variables as number ( $\mathrm{n}$ ) and percentage (\%). Conformity of the data to normal distribution was assessed with the Kolmogorov-Smirnov test. The Student's t-test or the Mann-Whitney $U$ test was used for comparing the groups. The chi-square or the Fisher's Exact test was used for the qualitative data. Logistic regression analysis (univariate and multivariate analyses) was performed to evaluate the factors affecting the success of the operation and complication status in both groups. Factors that were found to be significant in univariate analysis were included in the multivariate analysis. A value of $p<0.05$ was considered as statistically significant. 


\section{Results}

Among a total of 3362 patients, $317(9.4 \%)$ were included in the elderly group. The mean surface area of the stone was 412 $(245,5-700)$ and 417 (225-780) $\mathrm{mm}^{2}$ in the elderly and young groups, respectively. American Society of Anaesthesiologists (ASA) scores were higher for the former group. The demographic data of the patients are shown in Table 1. No statistically significant differences were determined between the groups in respect of laterality, access number, stone location, presence of hydronephrosis, mean operation time, mean duration of nephrostomy, mean length of stay in hospital, and type of anaesthesia $(p>0.05)$. Preoperative haemoglobin and GFR values were significantly lower and preoperative creatinine values were significantly higher $(p<0.01)$ in the elderly group than in the young group. Postoperative decrease in haemoglobin and postoperative $4^{\text {th }}$ week GFR changes of the groups were not significantly different from each other ( $p>0.05)$.

In both groups, the GFR increased significantly $(p<0.001)$ when the preoperative GFR and postoperative $4^{\text {th }}$ week GFR values were compared (Table 2).

There was no significant difference between the total complication rates of the groups ( $p=0.835)$. When complications were classified according to the Clavien classification, no significant differences were found. The percentages of complications of the groups according to the Clavien classification are shown in Table 3.

The SFR was higher in the elderly group and success rates were similar in both groups ( $p=0.002$ and $p=0.605$, respectively). Patients who did not benefit from PNL at the 4-week followup examination, underwent shock wave lithotripsy, second-look PNL, flexible renoscopy, or were followed up conservatively if the residual stones were asymptomatic. Comparisons of the groups according to the outcomes of the procedures are shown in Table 3.

Evaluation of the factors affecting the success rate and complications are shown in Table 4 and Table 5.

\section{Discussion}

The prevalence of various chronic diseases increases with ageing. Hence, with the current improvements in medical practices and prolonged life expectancy, it is inevitable that there is a greater proportion of the elderly population with chronic diseases (13-16). Although, age itself is not an illness, the presence of multiple morbidities in the elderly is a natural phenomenon of life. Limited renal function and cardiopulmonary capacity that are seen as a part of the natural process of ageing can reduce tolerance to invasive surgeries and long-term anaesthetic agents. The addition of concomitant comorbidities may also lead to a worsening of the cardiopulmonary reserve and increased anaesthetic risks for operations in the elderly patients $(17,18)$.

Urinary stone disease is a common health problem with an estimated prevalence of $6.3 \%$ and $4.1 \%$ in men and women, respectively (19). Like most chronic diseases, the prevalence has been reported to increase with ageing (20). In the current guidelines of the European Association of Urology, regardless of the age of the patient, PNL is recommended as a first line treatment for renal stones $>2 \mathrm{~cm}$ and is described as a minimally invasive procedure (21). However, it is associated with some complications, including death (22). The aim of this study was to compare the efficacy and safety of PNL in the elderly ( $\geq 65$ years) and young patients ( $<65$ years), and to investigate the factors affecting the outcomes and complication rates in both groups.

The main purpose of stone treatment should be maximum stone clearance in the first procedure with minimal complications. In the elderly population, the requirement for additional procedures may increase operation- or anaesthesia-related risks. Therefore, many surgeons prefer less invasive methods for their treatment. In a study by Akman et al. (18), the outcomes of PNL were compared with retrograde intrarenal surgery (RIRS) using matched-pair analysis ( $1: 1)$ of 28 patients aged $>65$ years. The SFR of the PNL group was higher than that of the RIRS group after a single procedure ( $92.8 \%$ vs $82.1 \%$, respectively). A second procedure was required for five patients (17.9\%) of the RIRS group. No significant difference was found in terms of complication rates between the groups. Despite the longer stay in hospital, longer operation time, and greater haemoglobin drop, PNL was seen to be a more successful method with a similar complication rate.

In a prospective study by Okeke et al. (7), ASA scores were reported to be higher and eGFR levels were lower in patients $>70$ years of age. In the same study, complication rates were found to be slightly higher in the elderly patients, the SFR was similar in both young and elderly patients and the length of hospital stay was found to be longer in the elderly group. In another study by Morganstern et al. (8), operative characteristics, SFR, and length of hospitalisation were similar in patients of the octogenarian and young groups who underwent PNL. Despite the risk factors, PNL has been shown to be safe and successful even in patients over 80 years of age. Sahin et al. (6) reported that success rate, complication rate, and hospital stay of patients older than 60 years were similar to those of a young group. The rate of postoperative fever and mean haemoglobin drop were higher in the elderly group but the difference was not statistically significant. Anagnostou et al. (9) compared two patient groups, aged 17-69 years and $>70$ years and reported no statistically significant difference between the groups in 


\begin{tabular}{|c|c|c|c|}
\hline & Elderly patients $(n=317)$ & Young patients $(n=3045)$ & p \\
\hline Age, years (median, IOR) & $69(66-72)$ & $47(37-55)$ & $<0.001$ \\
\hline \multicolumn{4}{|l|}{ Gender $\mathrm{n} / \%$} \\
\hline Male & $184(58)$ & $1900(62.4)$ & \multirow{2}{*}{0.129} \\
\hline Female & $133(42)$ & $1145(37.6)$ & \\
\hline \multicolumn{4}{|l|}{ Side $\mathrm{n} / \%$} \\
\hline Right & $150(47.3)$ & 1509 (49.6) & \multirow{2}{*}{0.243} \\
\hline Left & $167(52.7)$ & $1536(50.4)$ & \\
\hline Preoperative hemoglobin, g/dL (median, IQR) & $13.6(12.45-14.55)$ & $14.1(12.9-15.32)$ & $<0.001$ \\
\hline Preoperative creatinin, mg/dL (median, IQR) & $1(0.8-1.3)$ & $0.9(0.8-1.1)$ & $<0.001$ \\
\hline Preoperative GFR, mL/min/1,72 (median, IQR) & $66.18(66.18-82.61)$ & $84,25(68.52-101.19)$ & $<0.001$ \\
\hline Hemoglobin drop, (median, IQR) & $1.3(0.5-2)$ & $1.1(0.5-2)$ & 0.911 \\
\hline Postoperative GFR change, $($ mean \pm SD) & $3.72 \pm 5.84$ & $4.41 \pm 4.97$ & 0.192 \\
\hline Stone burden, $\mathrm{mm}^{2}$ (median, IQR) & $412(245.5-700)$ & $417(225-780)$ & 0.802 \\
\hline \multicolumn{4}{|l|}{ Stone location $\mathrm{n} / \%$} \\
\hline Single calyx & $174(54.9)$ & $1477(48.5)$ & \multirow{2}{*}{0.052} \\
\hline Multiple calyces & $143(45.1)$ & $1568(51.5)$ & \\
\hline \multicolumn{4}{|l|}{ Previous operation $\mathrm{n} / \%$} \\
\hline No & $250(78.9)$ & $2462(80.9)$ & \multirow{2}{*}{0.393} \\
\hline Yes & $67(21.1)$ & $583(19.1)$ & \\
\hline \multicolumn{4}{|l|}{ Hydronephrosis $\mathrm{n} / \%$} \\
\hline No & $83(26.2)$ & $812(26.7)$ & \multirow{2}{*}{0.853} \\
\hline Yes & $234(73.8)$ & $2233(73.3)$ & \\
\hline \multicolumn{4}{|l|}{ Staghorn Stone $\mathrm{n} / \%$} \\
\hline No & $276(87.1)$ & 2705 (88.8) & \multirow{2}{*}{0.345} \\
\hline Yes & $41(12.9)$ & $340(11.2)$ & \\
\hline \multicolumn{4}{|l|}{ Solitary Kidney n/\% } \\
\hline No & $302(95.3)$ & $2975(97.7)$ & \multirow{2}{*}{0.009} \\
\hline Yes & $15(4.7)$ & $70(2.3)$ & \\
\hline \multicolumn{4}{|l|}{ Horseshoe Kidney n/\% } \\
\hline No & $311(98.1)$ & 3977 (97.8) & \multirow{2}{*}{0.694} \\
\hline Yes & $6(1.9)$ & $68(2.2)$ & \\
\hline \multicolumn{4}{|l|}{ Type of anesthesia $n / \%$} \\
\hline General & $205(64.7)$ & $2121(69.7)$ & \multirow{2}{*}{0.067} \\
\hline Regional & $112(35.3)$ & $924(30.3)$ & \\
\hline \multicolumn{4}{|l|}{ Access number $\mathrm{n} / \%$} \\
\hline Single & $241(76)$ & 2235 (73.4) & \multirow{2}{*}{0.312} \\
\hline Multiple & $76(24)$ & $810(26.6)$ & \\
\hline GSS (median, IQR) & $1(1-2)$ & $2(1-2)$ & 0.245 \\
\hline Operation time, $\min ($ median, IQR) & $48.6(30-60)$ & $45(30-65)$ & 0.148 \\
\hline Duration with nephrostomy, days (median, IQR) & $2(2-3)$ & $2(2-3)$ & 0.807 \\
\hline Hospitilization day (median, IQR) & $3(2.5-4)$ & $3(2-4)$ & 0.121 \\
\hline \multicolumn{4}{|l|}{ ASA clasification $n / \%$} \\
\hline ASA 1 & $98(31)$ & $1827(60)$ & \multirow{3}{*}{$<0.001$} \\
\hline ASA 2 & $187(59)$ & $1065(35)$ & \\
\hline ASA 3 & $32(10)$ & $153(5)$ & \\
\hline
\end{tabular}


Table 2. Change of GFR values after $4^{\text {th }}$ week

\begin{tabular}{|l|l|l|l|}
\hline & $\begin{array}{l}\text { Preoperative } \\
\text { GFR }\end{array}$ & $\begin{array}{l}\text { Postoperative 4 } \\
\text { week GFR }\end{array}$ & p-value \\
\hline Elderly patients & $65.32 \pm 23.32$ & $69.04 \pm 23.74$ & $<0.001$ \\
\hline Young patients & $86.07 \pm 29.23$ & $90.49 \pm 28.29$ & $<0.001$ \\
\hline \multicolumn{2}{|l}{ GFR: Glomerular filtration rate } \\
\hline
\end{tabular}

Table 3. Comparison of elderly and young patients according to Clavien Classification and the surgical outcomes of PNL

\begin{tabular}{|c|c|c|c|}
\hline & $\begin{array}{l}\text { Elderly } \\
\text { patients } \\
(n=317) \\
n / \%\end{array}$ & $\begin{array}{l}\text { Young } \\
\text { patients } \\
(n=3045) \\
n / \%\end{array}$ & p-value \\
\hline \multicolumn{4}{|c|}{ Complications (According to Clavien) } \\
\hline Grade 1 (Fever) & $13(4.1)$ & $126(4.1)$ & 0.975 \\
\hline $\begin{array}{l}\text { Grade } 2 \\
\text { (Blood transfusion, urinary } \\
\text { tract infection) }\end{array}$ & $29(9.3)$ & $261(8.5)$ & 0.728 \\
\hline Grade 3a (Extravasation) & $4(1.2)$ & $55(1.8)$ & 0.085 \\
\hline $\begin{array}{l}\text { Grade } 3 b \text { (Perirenal } \\
\text { hematoma, arteriovenous } \\
\text { fistula) }\end{array}$ & $2(0.6)$ & $6(0.2)$ & 0.131 \\
\hline $\begin{array}{l}\text { Grade } 4 a \\
\text { (Colon injury, Pleural injury) }\end{array}$ & $3(0.9)$ & $36(1.2)$ & 0.709 \\
\hline Grade 4b (Sepsis) & $2(0.6)$ & $5(0.2)$ & 0.083 \\
\hline Grade 5 (Death) & $1(0.3)$ & $3(0.1)$ & 0.286 \\
\hline Total Complication Status & $43(13.6)$ & $420(13.8)$ & 0.911 \\
\hline \multicolumn{4}{|l|}{ Surgecal outcomes } \\
\hline Success rate & 307 (96.8) & $2962(97.3)$ & 0.658 \\
\hline Stone free rate & $294(92.7)$ & $2634(86.5)$ & 0.002 \\
\hline \multicolumn{3}{|c|}{ Additional treatment after PNL } & \\
\hline Follow-up & $8(80 \%)$ & $52(63 \%)$ & \\
\hline SWL & $2(20 \%)$ & $12(14 \%)$ & \\
\hline Second PNL & - & $10(12 \%)$ & \\
\hline RIRS & - & $9(11 \%)$ & \\
\hline
\end{tabular}

terms of the complication rates, SF rates, duration of surgery, and length of hospital stay. Buldu et al. (10) also showed similar results and reported that the postoperative haematocrit change was not different in the elderly patients compared with that of other age groups. In the current series, there was no significant difference between the two groups in terms of postoperative haemoglobin drop, complication rates, duration of surgery, or length of hospital stay. The success rates of the procedure were similar in both groups; however, the SFR was significantly higher in the elderly patients. This condition was associated with a higher Guy's Stone score (GSS), although not at a significant level, in the young patient group.
Table 4. Evaluation of factors for operation success in patient groups

Univariate analysis

\begin{tabular}{|c|c|c|c|c|c|c|}
\hline & \multicolumn{3}{|c|}{ Elderly patients } & \multicolumn{3}{|c|}{ Young patients } \\
\hline & $\mathbf{p}$ & OR & $95 \% \mathrm{Cl}$ & p & OR & $95 \% \mathrm{Cl}$ \\
\hline Age & 0.096 & 0.899 & $0.793-1.019$ & 0.078 & 1.017 & 0.998-1.036 \\
\hline Gender & 0.899 & 0.920 & $0.254-3.326$ & 0.231 & 0.751 & $0.470-1.202$ \\
\hline Stone burden & 0.009 & 0.999 & $0.999-1.000$ & $<0.001$ & 1.000 & 0.999-1.000 \\
\hline $\begin{array}{l}\text { Preop } \\
\text { Hemoglobin }\end{array}$ & 0.761 & 1.059 & $0.730-1.538$ & 0.367 & 1.068 & $0.946-1.206$ \\
\hline Preop GFR & 0.876 & 1.002 & $0.975-1.030$ & 0.590 & 1.002 & 0.994-1.010 \\
\hline Operation time & 0.025 & 0.988 & 0.978-0.999 & $<0.001$ & 0.982 & 0.977-0.986 \\
\hline Access number & 0.014 & 5.079 & 1.394-18.504 & $<0.001$ & 0.623 & $0.522-0.742$ \\
\hline $\begin{array}{l}\text { Type of A } \\
\text { nesthesia }\end{array}$ & 0.721 & 0.779 & $0.197-3.072$ & 0.209 & 0.723 & $0.434-1.202$ \\
\hline Side & 0.077 & 6.522 & $0.816-52.124$ & 0.028 & 0.608 & $0.389-0.952$ \\
\hline Hydronephosis & 0.651 & 1.434 & $0.298-6.892$ & 0.055 & 1.817 & $1.017-3.247$ \\
\hline GSS & 0.012 & 0.517 & $0.310-0.865$ & $<0.001$ & 0.462 & $0.383-0.556$ \\
\hline $\begin{array}{l}\text { Previous } \\
\text { Operation }\end{array}$ & 0.485 & 1.627 & $0.409-6.470$ & 0.801 & 0.903 & $0.528-1.638$ \\
\hline Staghorn stone & 0.018 & 4.865 & $1.311-18.048$ & $<0.001$ & 5.708 & $3.621-8.998$ \\
\hline \multicolumn{7}{|c|}{ Multivariate analysis } \\
\hline Stone burden & 0.371 & 1.000 & 0.999-1.000 & 0.133 & 1.000 & $1.000-1.000$ \\
\hline Operation time & 0.027 & 0.991 & 0.983-0.999 & $<0.001$ & 0.988 & $0.982-0.993$ \\
\hline Access number & 0.614 & 0.832 & $0.407-1.700$ & 0.879 & 0.983 & $0.788-1.226$ \\
\hline GSS & 0.574 & 0.638 & $0.133-3.059$ & 0.001 & 0.373 & $0.212-0.656$ \\
\hline Staghorn stone & 0.834 & 0.652 & $0.012-35.595$ & 0.061 & 0.281 & $0.074-1.061$ \\
\hline
\end{tabular}

Kurien et al. (23) reported that $86.8 \%$ of patients with preoperative CKD had stable or improved eGFR after PNL. Therefore, it has been suggested that patients with CKD who have PNL indications should receive preventive treatment. In a study by Besiroglu et al. (24), the data of 283 male patients who underwent PNL were evaluated retrospectively. The patients were divided into four age groups of 40-49, 50-59, 60-69, and over 70 years. An improvement in eGFR values was detected at the end of the $6^{\text {th }}$ month in all groups. Caglayan et al. (25) retrospectively evaluated the data of 82 patients with a solitary kidney. The renal functions were preserved in patients with a normal functioning kidney and improved in patients with renal insufficiency. According to the current study results, the mean GFR increased at the four-week follow-up examination and the improvement of renal function was similar in both groups.

Higher GSS and stone burden have been shown to be predictors of unsuccessful results and complications after PNL $(26,27)$; the same trend was seen in our series too. PNL for staghorn stones 


\begin{tabular}{|c|c|c|c|c|c|c|}
\hline \multicolumn{7}{|l|}{ Univariate analysis } \\
\hline & \multicolumn{3}{|c|}{ Elderly patients } & \multicolumn{3}{|c|}{ Young patients } \\
\hline Age & $<0.001$ & 1.149 & $1.071-1.232$ & 0.564 & 0.997 & 0.989-1.006 \\
\hline Gender & 0.859 & 0.943 & $0.496-1.795$ & 0.009 & 0.758 & $0.615-0.934$ \\
\hline Preop Hemoglobin & 0.010 & 0.778 & $0.643-0.941$ & $<0.001$ & 0.805 & $0.760-0.852$ \\
\hline Preop GFR & 0.631 & 0.997 & $0.983-1.010$ & 0.518 & 0.999 & 0.995-1.002 \\
\hline Operation time & 0.029 & 1.007 & $1.000-1.015$ & $<0.001$ & 1.014 & $1.011-1.016$ \\
\hline Access number & 0.182 & 1.312 & $0.881-1.955$ & $<0.001$ & 1.647 & $1.484-1.829$ \\
\hline GSS & 0.020 & 1.405 & $1.054-1.873$ & $<0.001$ & 1.485 & $1.345-1.639$ \\
\hline Previous operation & 0.095 & 2.292 & $0.866-6.065$ & 0.261 & 1.168 & $0.891-1.533$ \\
\hline Staghorn stone & 0.041 & 0.436 & $0.196-0.967$ & $<0.001$ & 0.359 & $0.275-0.467$ \\
\hline \multicolumn{7}{|l|}{ Multivariate analysis } \\
\hline Age & $<0.001$ & 1.145 & $1.064-1.233$ & - & - & - \\
\hline Gender & - & - & - & 0.654 & 1.059 & $0.824-1.362$ \\
\hline Stone burden & 0.738 & 1.000 & $1.000-1.001$ & 0.159 & 1.000 & $1.000-1.000$ \\
\hline Preop hemoglobin & 0.027 & 0.787 & $0.636-0.973$ & $<0.001$ & 0.791 & $0.740-0.846$ \\
\hline Operation time & 0.036 & 1.006 & $1.005-1.011$ & $<0.001$ & 1.009 & 1.005-1.012 \\
\hline
\end{tabular}

has been reported to be associated with lower SFR, and higher rates of complications and blood transfusion when compared with PNL for non-staghorn stones (28-30). Kuzgunbay et al. (31) compared the efficacy and safety of PNL in staghorn stones in the elderly patients with that in young patients. There was no difference between the groups in terms of operation success and complication rates. In accordance with this finding, the presence of staghorn stones was a factor that negatively affected the success and complication rates in the current series; although, there were no significant differences in the success and complication rates of the groups (success rate: $95.1 \%$ in elderly patients, $90.3 \%$ in young patients, $\mathrm{p}=0.312$; complication rate: $24.4 \%$ and $27.6 \%$ respectively, $p=0.658$; not shown in the tables).

Prolonged operation time has been demonstrated to be associated with higher complication rates $(32,33)$. The latter may also be affected by factors such as increased number of tracts, increased manipulation of the nephroscope, the presence of complex stones, or a less experienced surgeon; thereby prolonging the operation time. According to the results of the current study, prolonged operation time was a significant risk factor for complications regardless of the age of the patients.

The treatment of renal stones in the elderly population is a major concern even for the most experienced urologists. The results of the current study demonstrated that PNL in the elderly provides similar success and complications rates as in young patients. With good preoperative preparation and close postoperative monitoring, it can be considered as a safe method to be employed at experienced centres.

\section{Study Limitations}

There were some limitations of the current study; primarily, its retrospective design and its premise at a single centre that may limit the generalisation of results. The SFR was higher in the elderly population and matched-pair analysis would have excluded the selection bias. Another limitation was that miniPNL, a standard procedure at many centres, is not performed at 
our centre. Hence, it was not possible to compare the outcomes of mini-PNL in the elderly and young populations.

\section{Conclusion}

The outcomes of PNL and the factors affecting success and complication rates of the procedure were similar in both elderly and young patients. PNL can be considered as a safe and effective treatment modality regardless of the age of the patient.

\section{Ethics}

Ethics Committee Approval: Approval for the study was granted by the Institutional Ethics Committee (approval no: 2011-KAEK25 2020/01-06, date: 29.01.2020).

Informed Consent: Retrospective study.

Peer-review: Externally peer-reviewed.

\section{Authorship Contributions}

Concept: E.Ö., V.Ç., Design: E.Ö., Data Collection or Processing: E.Ö., V.Ç., Analysis or Interpretation: E.Ö., V.Ç., Literature Search: V.Ç., Writing: E.Ö., V.Ç.,

Conflict of Interest: No conflict of interest was declared by the authors.

Financial Disclosure: The authors declared that this study received no financial support.

\section{References}

1. Gupta M, Bolton DM, Gupta PN, Stoller ML. Improved renal function following aggressive treatment of urolithiasis and concurrent mild to moderate renal insufficiency. J Urol 1994;152:1086-1090.

2. Stoller ML, Bolton D, St Lezin M, Lawrence M. Percutaneous nephrolithotomy in the elderly. Urology 1994;44:651-654.

3. Smith R, Osterweil D, Ouslander JG. Perioperative care in the elderly urologic patient. Urol Clin North Am 1996;23:27-41.

4. Tonner PH, Kampen J, Scholz J. Pathophysiological changes in the elderly Best Pract Res Clin Anaesthesiol 2003;17:163-177.

5. Fernström I, Johansson B. Percutaneous pyelolithotomy. A new extraction technique. Scand J Urol Nephrol 1976;10:257-259.

6. Sahin A, Atsü N, Erdem E, Oner S, Bilen C, Bakkaloğlu M, Kendi S. Percutaneous nephrolithotomy in patients aged 60 years or older. J Endourol 2001:15:489-491.

7. Okeke $Z$, Smith $A D$, Labate $G$, D'Addessi $A$, Venkatesh $R$, Assimos $D$, Strijbos WEM, de la Rosette JJMCH. CROES PCNL Study Group. Prospective comparison of outcomes of percutaneous nephrolithotomy in elderly patients versus younger patients. J Endourol 2012;26:996-1001.

8. Morganstern B, Galli R, Motamedinia P, Leavitt D, Keheila M, Ghiraldi E, Hoenig D, Smith A, Okeke Z. Percutaneous nephrolithotomy in octogenarians and beyond: How old is too old? Asian J Urol 2015;2:208-213.

9. Anagnostou T, Thompson T, Ng CF, Moussa S, Smith G, Tolley DA. Safety and outcome of percutaneous nephrolithotomy in the elderly: retrospective comparison to a younger patient group. J Endourol 2008;22:2139-2145.
10. Buldu I, Tepeler A, Karatag T, Bodakci MN, Hatipoglu NK, Penbegul N, Akman T, Istanbulluoglu 0, Armagan A. Does aging affect the outcome of percutaneous nephrolithotomy? Urolithiasis 2015;43:183-187.

11. Levey AS, Stevens LA, Schmid CH, Zhang YL, Castro AF, Feldman HI, Kusek JW, Eggers P, Van Lente F, Greene T, Coresh J. A new equation to estimate glomerular filtration rate; CKD-EPI (Chronic Kidney Disease Epidemiology Collaboration). Ann Intern Med 2009;150:604-612.

12. Tefekli A, Ali Karadag M, Tepeler K, Sari E, Berberoglu Y, Baykal M, Sarilar 0 , Muslumanoglu AY. Classification of percutaneous nephrolithotomy complications using the modified Clavien grading system, looking for a standard. Eur Urol 2008;53:184-190.

13. Barnett K, Mercer SW, Norbury M, Watt G, Wyke S, Guthrie B. Epidemiology of multimorbidity and implications for health care, research, and medical education: a cross-sectional study. Lancet 2012:380:37-43.

14. King DE, Xiang J, Pilkerton CS. Multimorbidity trends in United States adults, 1988-2014. J Am Board Fam Med 2018;31:503-513.

15. Chen $\mathrm{H}$, Cheng M, Zhuang Y, Broad JB. Multimorbidity among middle-aged and older persons in urban China: prevalence, characteristics and health service utilization. Geriatr Gerontol Int 2018:18:1447-1452.

16. Violan C, Foguet-Boreu O, Flores-Mateo G, Salisbury C, Blom J, Freitag M, Glynn L, Muth C, Valderas JM. Prevalence, determinants and patterns of multimorbidity in primary care: a systematic review of observational studies. PLoS One 2014;9:e102149.

17. $\mathrm{Ng}$ CF. The effect of age on outcomes in patients undergoing treatment for renal stones. Curr Opin Urol 2009;19:211-214.

18. Akman $T$, Binbay $M$, Ugurlu $M$, Kaba $M$, Akcay $M$, Yazici 0 , Ozgor $F_{1}$ Muslumanoglu AY. Outcomes of retrograde intrarenal surgery compared with percutaneous nephrolithotomy in elderly patients with moderate-size kidney stones: a matched-pair analysis. J Endourol 2012;26:625-629.

19. Stamatelou KK, Francis ME, Jones CA, Nyberg LM, Curhan GC. Time trends in reported prevalence of kidney stones in the United States: 1976-1994. Kidney Int 2003;63:1817-1823.

20. Scales CD Jr, Smith AC, Hanley JM, Saigal CS. Urologic diseases in America Project: Prevalence of kidney stones in the United States. Eur Urol 2012;62:160-165

21. Turk C, Skolarikos A, Neisius A, Petrik A, Seitz C, Thomas K. Guidelines on Urolithiasis. https://uroweb.org/wp-content/uploads/EAU-Guidelines-onUrolithiasis-2019.pdf

22. Michel MS, Trojan L, Rassweiler JJ. Complications in percutaneous nephrolithotomy. Eur Urol 2007;51:899-906.

23. Kurien A, Baishya R, Mishra S, Ganpule A, Muthu V, Sabnis R, Desai M. The impact of percutaneous nephrolithotomy in patients with chronic kidney disease. J Endourol 2009;23:1403-1407.

24. Besiroglu H, Merder $E$, Dedekarginoglu G. Percutaneous nephrolithotomy is safe and effective in aging male patients: a single center experience. Aging Male 2019;12:1-6.

25. Caglayan V, Oner $S$, Onen $E$, Avci $S$, Aydos M, Kilic M, Demirbas M. Percutaneous nephrolithotomy in solitary kidneys: effective, safe and improves renal functions. Minerva Urol Nefrol 2018;70:518-525.

26. Jiang K, Sun F, Zhu J, Luo G, Zhang P, Ban Y, Shan G, Liu C. Evaluation of three stone-scoring systems for predicting SFR and complications after percutaneous nephrolithotomy: a systematic review and meta-analysis. BMC Urol 2019;19:57.

27. Al-Adl AM, Mohey A, Abdelaal A, Abu-Elnasr HAF, El-Karamany T, Noureldin YA. Percutaneous Nephrolithotomy Outcomes Based on S.T.O.N.E., GUY CROES, and S-ReSC Scoring Systems: The First Prospective Study. J Endourol. doi: 10.1089/end.2019.0856. (Online ahead of print).

28. Desai M, De Lisa A, Turna B, Rioja J, Walfridsson H, D'Addessi A, Wong C Rosette J. On Behalf Of The Croes Pcnl Study Group J. The clinical research office of the endourological society percutaneous nephrolithotomy global 
study: staghorn versus nonstaghorn stones. J Endourol 2011;25:1263-1268.

29. El-Nahas AR, Elshal AM, El-Tabey NA, El-Assmy AM, Shokeir AA. Percutaneous nephrolithotomy for staghorn stones: a randomised trial comparing high-power holmium laser versus ultrasonic lithotripsy. BJU Int 2016;118:307-312.

30. Ghani KR, Andonian S, Bultitude M, Desai M, Giusti G, Okhunov Z, Preminger GM, de la Rosette J. Percutaneous nephrolithotomy: update, trends, and future directions. Eur Urol 2016;70:382-396.
31. Kuzgunbay B, Turunc T, Yaycioglu 0, Kayis AA, Gul U, Egilmez T, Aygun C, Ozkardes H. Percutaneous nephrolithotomy for staghorn kidney Stones in elderly patients. Int Urol Nephrol 2011;43:639-643.

32. Nakamon T, Kitirattrakarn P, Lojanapiwat B. Outcomes of percutaneous nephrolithotomy: comparison of elderly and younger patients. Int Braz J Urol 2013;39:692-700.

33. Oner $\mathrm{S}$, Okumus MM, Demirbas M, Onen E, Aydos MM, Ustun MH, Kilic M, Avci S. Factors influencing complications of percutaneous nephrolithotomy: a single-center study. Urol J 2015;12:2317-2323. 